\title{
Selective Gene Expression in Magnocellular Neurons in Rat Supraoptic Nucleus
}

\author{
Noriko Mutsuga, ${ }^{1}$ Tal Shahar, ${ }^{1}$ Joseph G. Verbalis, ${ }^{3}$ Michael J. Brownstein, ${ }^{2}$ Charlie C. Xiang, ${ }^{2}$ \\ Robert F. Bonner, ${ }^{4}$ and Harold Gainer ${ }^{1}$ \\ ${ }^{1}$ Laboratory of Neurochemistry, National Institute of Neurological Disorders and Stroke, National Institutes of Health, ${ }^{2}$ Laboratory of Genetics, National \\ Institute of Mental Health, National Institutes of Health, Bethesda, Maryland 20892, ${ }^{3}$ Department of Medicine, Division of Endocrinology and Metabolism, \\ Georgetown University, Washington, DC 20007, and ${ }^{4}$ Laboratory of Integrative and Medical Biophysics, National Institute of Child Health and Human \\ Development, National Institutes of Health, Bethesda, Maryland 20892-5772
}

Oxytocin- and vasopressin-producing magnocellular neurons (MCNs) of the hypothalamo-neurohypophysial system are the only neuronal phenotypes present in the rat supraoptic nucleus (SON). Laser microdissection of the SON, extraction and T7-based amplification of its RNAs, and analysis of the resulting cDNAs by hybridization on a 35, 319 element DNA microarray have provided a detailed composite view of the gene expression profile of the MCNs. The genes expressed in the SON were compared with those expressed in a reference tissue consisting of total hypothalamus, and this "expression ratio" indicated which genes were preferentially expressed in the SON. Of the 26,000 unique genes on the array, 1385 were found to be expressed in the SON at levels more than two times greater than in the hypothalamus as a whole. Of these, 123 were expressed $\geq 3.4$-fold higher in the SON versus hypothalamus. Most of these preferentially expressed genes were not previously known to be expressed in the MCNs. Quantitative and double-label in situ hybridization histochemistry was used selectively to confirm a number of these microarray observations and to evaluate the osmotic regulation and cell-specific expression of these genes, respectively.

Key words: oxytocin; vasopressin; hypothalamus; gene expression; microarray; laser microdissection

\section{Introduction}

The hypothalamo-neurohypophysial system is the major neuroendocrine system through which the brain maintains body fluid homeostasis (Robertson, 1995; Antunes-Rodrigues et al., 2004). The axons of the vasopressin (VP)- and oxytocin (OT)synthesizing magnocellular neurons (MCNs) located in the supraoptic and paraventricular hypothalamic nuclei of the hypothalamus terminate on the capillaries of the posterior pituitary, into which the peptides are secreted (Brownstein et al., 1980; Sladek, 1999). The high rates of neuropeptide synthesis, transport, and release by the VP- and OT-MCNs, and their discrete localization in the hypothalamus, have made these cells important experimental models for the study of peptidergic neuronal cell biology in the CNS (Young, 1992; Gainer and Wray, 1994; Burbach et al., 1995, 2001; Waller et al., 1998; Sladek, 1999).

The aim of this study was to determine which genes are selec-

Received May 25, 2004; revised June 24, 2004; accepted June 28, 2004.

This work was supported in part by the Japan Society for Promotion in Science. We thank Dr. Ying Tian (Georgetown University, Washington, DC) for help with preparation of the animals, Dr. Eva Mezey and Sharon Key [National Institute of Neurological Disorders and Stroke (NINDS), National Institutes of Health (NIH), Bethesda, MD] for help with in situ hybridization histochemistry, Dr. Yidong Chen (National Human Genome Research Institute, NIH, Bethesda, MD) for help with statistical analysis for microarray data, Catherine Campbell for suggestions about microarray analysis, Raymond L. Fields for technical assistance, and James W. Nagle and Debbie Kauffman (NINDS, DNA sequencing Facility, NIH, Bethesda, MD) for DNA sequencing.

Correspondence should be addressed to Dr. Harold Gainer, Laboratory of Neurochemistry, National Institute of Neurological Disorders and Stroke, National Institutes of Health, Bethesda, MD 20892. E-mail: gainerh@ninds.nih.gov. DOI:10.1523/JNEUROSCI.2022-04.2004

Copyright $@ 2004$ Society for Neuroscience $\quad 0270-6474 / 04 / 247174-12 \$ 15.00 / 0$ tively expressed in the supraoptic nucleus (SON) to identify genes that might regulate the expression of the neuropeptides and other characteristic features of the MCNs. Previous studies of handmicrodissected supraoptic nuclei (Glasgow et al., 2000) or single MCNs isolated from the SON (Glasgow et al., 1999; Yamashita et al., 2002) relied on PCR amplification of the extracted RNA and differential cloning procedures. Some osmotically regulated and MCN-specific genes were identified, but few transcription factors were discovered. This was attributable, in part, to the limitations of the nonlinear PCR amplification used in those studies and the generally low levels of expression of such factors. Therefore, in this study, we used laser microdissection of the SON and linear amplification of the extracted RNA, in combination with DNA microarray analysis of gene expression. Laser microdissection allows for the selective collection of cells of interest from tissue sections, and microarray techniques permit the analysis of several thousand genes in a single sample. The combination of the two techniques has been used to profile gene expression in adjacent neuronal subtypes within the CNS (Luo et al., 1999). We used a linear T7-based RNA amplification of total SON RNA isolated by laser microdissection, and the probes generated from this RNA were subsequently analyzed by hybridization on a 35,319 element cDNA microarray.

We used an approach in which genes in the tissue sample of interest (i.e., the SON) are compared with those in a reference tissue sample (Perou et al., 2000; Garber et al., 2001; Yang et al., 2002) on single arrays. Total hypothalamus tissue served as the 
reference tissue. The ratios of the SON to the hypothalamic signals are a measure of the preferential expression of specific genes in the MCNs in the SON relative to the hypothalamus, and we refer to this as the "expression ratio." We selectively validated genes with high expression ratios by in situ hybridization histochemistry. Overall, this strategy resulted in the identification of 123 preferentially expressed MCN genes, most of them not previously known to be expressed in the MCNs. Among these, 19 of the preferentially expressed genes found in the SON are potentially involved in transcription or translation.

\section{Materials and Methods \\ Animals}

Adult male Sprague Dawley rats weighing 260-320 gm were housed individually in wire-mesh cages in a temperature-controlled room (21$23^{\circ} \mathrm{C}$ ) with lights on from 7:00 A.M. to 7:00 P.M. All procedures were performed in accordance with National Institutes of Health (NIH) guidelines on the care and use of animals and an animal study protocol approved by the Georgetown University Animal Use and Care Committee. Hypernatremic rats were given $2 \% \mathrm{NaCl}$ in their drinking water for $7 \mathrm{~d}$. The plasma $\mathrm{Na}^{+}$levels (mM) and plasma osmolarities (mOsm $/ \mathrm{kg}$ $\mathrm{H}_{2} \mathrm{O}$ ) were measured in blood samples drawn via jugular puncture in each animal after $7 \mathrm{~d}$ of treatment. The plasma $\mathrm{Na}^{+}$levels were $139.8 \pm$ $0.9 \mathrm{~mm}$ and $152.6 \pm 6.7 \mathrm{~mm}$ and the plasma osmolarities were $288.8 \pm 2.2$ $\mathrm{mOsm} / \mathrm{kg} \mathrm{H}_{2} \mathrm{O}$ and $307.0 \pm 9.7 \mathrm{mOsm} / \mathrm{kg} \mathrm{H}_{2} \mathrm{O}$ in the normosmolar and hyperosmolar rats, respectively.

\section{Tissues}

Laser microdissection of the SON (see Fig. 1). After decapitation, the brains were removed quickly and frozen immediately on dry ice and stored at $-80^{\circ} \mathrm{C}$ until further processing occurred. The tissue was placed in the cryostat for $10 \mathrm{~min}$ at the cutting temperature $\left(-18^{\circ} \mathrm{C}\right)$ for temperature equilibration. Seven-micrometer-thick sections of the SON region were cut, placed on membrane-coated glass slides (glass foil polyethylennaphtalate slides; Leica Microsystems Inc., Bannockburn, IL), and stored immediately in a slide box embedded in dry ice until the sectioning was completed. The sections were stored at $-80^{\circ} \mathrm{C}$ until they were used. Before laser microdissection, the tissue was fixed and dehydrated with ethanol as described previously (Luo et al., 1999). Briefly, the slides were thawed for $45 \mathrm{sec}$ in $75 \%$ ethanol and further dehydrated by sequential immersion in $95 \%, 100 \%$ and again with $100 \%$ ethanol for 5 sec each. Then, the slides were cleared twice with xylene for $2 \mathrm{~min}$ and dried in a vacuum chamber. All of the solutions for fixation were prepared with DEPC water. Laser microdissection was performed under dark-field illumination using a laser-microdissection microscope (Leica Microsystems Inc.) (Kolble, 2000) immediately after dehydration of the slides. Brains from three animals were microdissected. The dissected supraoptic nuclei (Fig. $1 B$ ) were collected into $0.5 \mathrm{ml}$ tubes with $70 \mu \mathrm{l}$ of lysis buffer containing guanidine thiocyanate and $0.5 \mu \mathrm{l}$ of $\beta$-mercaptoethanol.

Collection of hypothalamic reference tissue. Blocks of hypothalamic tissue were obtained from 10 control male rats. After decapitation, the brains were removed from the skull and placed ventral side up on a rubber stopper. Coronal cuts were made rostral to the optic chiasm and caudal to the cerebral peduncle. The hypothalamus was removed from the resulting brain slices by making a cut at the top of the third ventricle and cuts at the lateral margins of the optic tracts (Fig. $1 A$ ). The tissue samples were frozen in liquid nitrogen and stored at $-80^{\circ} \mathrm{C}$ until they were extracted.

\section{RNA extraction}

Laser microdissected SON tissue. RNA isolation was preformed according to the manufacture's protocol with the Absolutely RNA Microprep kit (Stratagene, La Jolla, CA) (Dolter and Braman, 2001). After extraction, total RNA was measured using a Ribogreen RNA quantitation kit (Molecular Probes, Eugene, OR). The samples and the standard RNAs were excited at $485 \mathrm{~nm}$, and the fluorescence emission intensity was measured at $535 \mathrm{~nm}$ using a fluorescence microplate reader (VICTOR2 $1420 \mathrm{Mul}-$ tilabel counter; Wallac Oy, Turku, Finland). Fluorescence emission in-
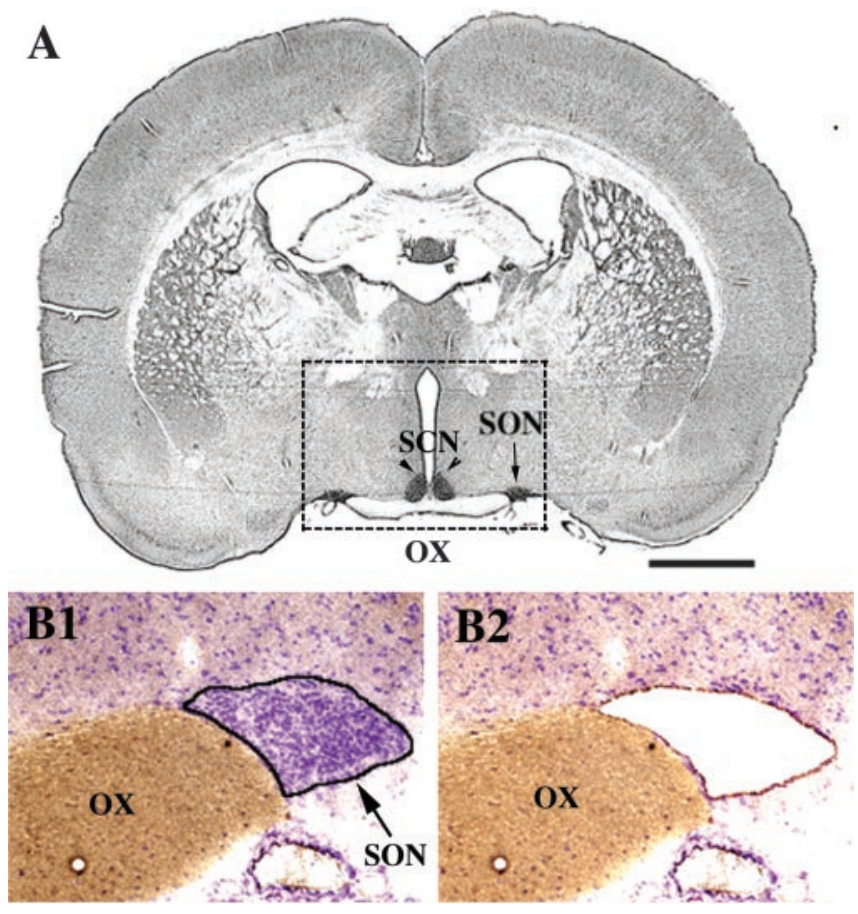

Figure 1. Illustration of a Nissl-stained coronal section of the rat hypothalamus and highpower views of an intact and laser-microdissected SON stained by Nissl. A, Arrows indicate the intense Nissl staining of MCNs in the SON and neurons in the suprachiasmatic nucleus (SCN). The dashed square indicates the region used as the reference for the array analysis (see Materials and Methods). OX, Optic chiasm. B, Nissl-stained SON region before (B1) and after (B2) laser microdissection. The arrow indicates MCNs in the SON, and the line in $B 1$ indicates the border of the region that was actually dissected by the laser. Scale bar: (in $A) A, 2 \mathrm{~mm} ; B, 0.33 \mathrm{~mm}$.

tensity of the samples was then plotted against an RNA standard curve. The average total RNA obtained from a pair of supraoptic nuclei from a single animal was $193.2 \mathrm{ng}$. Equal amounts of total RNA were pooled from each of three animals, and $150 \mathrm{ng}$ per pool was used as the template for T7-based RNA amplification (see below). Two groups of pooled RNA samples were made.

Reference hypothalamic tissue. RNA extraction of the dissected hypothalamic blocks was done using Trizol (Life Technologies, Gaithersburg, MD) (Chomczynski and Sacchi, 1987), followed by DNaseI (GenHunter, Nashville, TN), and the product was cleaned up using an Absolutely RNA Microprep kit (Stratagene). Approximately $200 \mu \mathrm{g}$ of total RNA was obtained from each block, and $5 \mu \mathrm{g}$ of the RNA from each of the 10 animals was pooled together. One hundred fifty nanograms of the pool of RNA were amplified using T7-based RNA amplification. Thus, we used $150 \mathrm{ng}$ of the pooled hypothalamic tissue RNA and the SON RNA in each reaction to obtain consistent amplification of the two samples.

\section{T7-based RNA amplification}

The RNA amplification was performed according to the manufacturer's protocol using the RiboAmp RNA Amplification kit (Arcturus, Mountain View, CA). The principles of this amplification have been described previously (Phillips and Eberwine, 1996). The first round of amplification was performed on $150 \mathrm{ng}$ of the pooled hypothalamic reference and $150 \mathrm{ng}$ of laser-microdissected SON material. For the second round, 500 ng of antisense RNA (aRNA) was collected from each of the samples and used as a template. The total amount of the RNA produced was measured using a spectrophometer (Ultrospec 2100 pro UV/Visible spectrophometer; Amersham Biosciences, Piscataway, NJ). The total amount of RNA produced in the first-round amplification of reference RNA was $10.6 \mu \mathrm{g}$, and the SON RNA was $6.6 \mu \mathrm{g}$. The total aRNAs from the second round were $138 \mu \mathrm{g}$ and $198 \mu \mathrm{g}$ for the hypothalamic reference and SON, respectively. The 260/280 ratios for the RNA sample after the second round ranged from 2.2 to 2.4 , and the sample spectrum from $\mathrm{OD}_{230}$ to $\mathrm{OD}_{320}$ was that expected for pure RNAs. The length of the aRNAs ranged from 
300 to $1300 \mathrm{bp}$ after the first round and from 300 to $700 \mathrm{bp}$ after the second round of amplification.

\section{Microarray fabrication}

Mouse DNA microarrays were printed on polyL-lysine-coated slides. The cDNA libraries that were used to print the array were provided by Dr. Bento Soares (University of Iowa, Iowa City, IA; http://genome.uiowa.edu/projects/ BMAP/; adult whole-brain cDNA library) and Dr. Minoru Ko (National Institute on Aging, NIH, Bethesda, MD; http://gsun.grc.nia. nih.gov/cDNA/cDNA.html; embryonic brain cDNA library). Plasmids were extracted from the bacteria using QiaPrep Turbo kits (Qiagen, Valencia, CA) and a BioRobot 8000 (Qiagen). The cDNA inserts were amplified with modified M13 primers (M13F, 5'-GTTGTAAAACGACGGCCAGTG-3'; M13R, 5'-CACACAGGAAACAGCTATG-3') and purified with MultiScreen PCR plates (Millipore, Bedford, MA). The PCR products were diluted in $50 \%$ DMSO to an average concentration of $200 \mathrm{ng} /$ $\mu$ l. These products ( $5 \mu \mathrm{l} \mathrm{each)}$ were transferred to 384-well plates (Genetix, St. James, NY) and then printed using an OmniGrid arrayer (GeneMachines, San Carlos, CA). The printed slides were aged for 1 week and then postprocessed before hybridization. For detailed descriptions of these procedures, visit the following web site: http://cmgm.stanford.edu/ pbrown/mguide/index.html. To validate the dissections of the SON sample, we added rat $\mathrm{VP}$ and OT cDNAs to the arrays.

\section{Microarray properties}

The 35,319 elements printed include 11,720 product-defined clones and 23,599 productundefined clones. The number of unigene clusters represented is 26,000 . We found that cross-hybridization of mouse and rat hypothalamic RNAs on this array was $94 \%$, indicating that it was appropriate for use for gene expression analysis of the rat hypothalamus (Fig. 2).

\section{Probe labeling with amine-modified random primers}

Probes were synthesized from $2 \mu \mathrm{g}$ of amplified total RNA. The SON was labeled with cyanine 5 (Cy5), and the reference was labeled with cyanine 3 (Cy3). The labeling was performed as described previously (Xiang et al., 2002,2003 ) with a minor modification. Briefly, the RNA was combined with $4 \mu \mathrm{g}$ of amine-modified random primer (amine-C6-TNNNNNN; Sigma Genosys, The Woodlands, TX) and 5 U of RNase inhibitor (RNasin; Promega, Madison, WI) in a total volume of $18.5 \mu \mathrm{l}$, incubated at $70^{\circ} \mathrm{C}$ for 10 $\mathrm{min}$, and chilled on ice for $10 \mathrm{~min}$. The primer/RNA solution [ $6 \mu$ lof $5 \times$ first-strand buffer (Life Technologies), $0.6 \mu$ l of $50 \times$ aminoallyl dUTP/ dNTPs (25 mm dATP, dGTP, and dCTP; 15 mm dTTP; and $10 \mathrm{~mm}$ aminoallyl dUTP; Sigma, St. Louis, MO), $3 \mu \mathrm{l}$ of 0.1 м DTT, $2 \mu \mathrm{l}$ of SuperScript II reverse transcriptase (Life Technologies)] was then added and incubated at $42^{\circ} \mathrm{C}$ for $2 \mathrm{hr}$. The reaction was terminated with $10 \mu \mathrm{l}$ of $0.5 \mathrm{M} \mathrm{EDTA}$, and the RNA was hydrolyzed with $10 \mu \mathrm{l}$ of $1 \mathrm{~N} \mathrm{NaOH}$ at $65^{\circ} \mathrm{C}$ for $30 \mathrm{~min}$. The solution was neutralized with $10 \mu \mathrm{l}$ of $1 \mathrm{M} \mathrm{HCl}$, and the MinElute PCR purification kit (Qiagen) was used to purify the products. The samples were concentrated to $9 \mu \mathrm{l}$ in a vacuum centrifuge, and then $1 \mu \mathrm{l}$ of $1 \mathrm{M}$ sodium bicarbonate, $\mathrm{pH} 9.3$, was added to the cDNA solution, followed by $14.5 \mu \mathrm{l}$ of dye solution [NHS-ester Cy3 or Cy5 (Amersham Biosciences), $62.5 \mu \mathrm{g} / \mu \mathrm{l}$ in DMSO]. The resulting solution was mixed by pipetting it up and down several times and was incubated at room temperature for $1 \mathrm{hr}$ in the dark. The labeling reaction was stopped with $4.5 \mu \mathrm{l}$ of $4 \mathrm{~m}$ hydroxylamine hydrochloride (Sigma). The contents of the tube were mixed, briefly centrifuged, and incubated for $30 \mathrm{~min}$ at room temperature in the dark. The probes were purified using the QIAquick PCR purification kit (Qiagen). The products were concentrated to $17 \mu \mathrm{l}$ in a vacuum centrifuge. Then, $4.5 \mu \mathrm{l}$ of $20 \times \mathrm{SSC}$, $2 \mu \mathrm{l}$ of poly(A) (A60mer, $10 \mathrm{mg} / \mathrm{ml}$; Sigma Genosys), $1 \mu \mathrm{l}$ of human Cot-1 DNA (10 mg/ml; Life Technologies), and $1 \mu$ l of yeast tRNA ( $4 \mathrm{mg} / \mathrm{ml}$; Life Technologies) was added, and the probes were denatured at $98^{\circ} \mathrm{C}$ for $2 \mathrm{~min}$. The arrays were prehybridized to $5 \times \mathrm{SSC} / 0.1 \%$ SDS/ $1 \%$ BSA solution at $42^{\circ} \mathrm{C}$ for $1 \mathrm{hr}$, washed in $\mathrm{H}_{2} \mathrm{O}$ for $2 \mathrm{~min}$, rinsed in isopropanol, and centrifuged at $800 \mathrm{rpm}$ for $2 \mathrm{~min}$ to dry. The denatured probes were combined with $20 \mu$ l of $2 \times$ hybridization buffer (50\% formamide, $10 \times$ SSC, and $0.2 \%$ SDS). The hybridization solution was pipetted onto the array, coverslips were applied, and the slides were placed in a hybridization chamber (Corning, Corning, NY). The slides were incubated in a $42^{\circ} \mathrm{C}$ water bath for $16 \mathrm{hr}$, the coverslips were removed in $2 \times \mathrm{SSC} / 0.1 \% \mathrm{SDS}$, and the slides were washed in $0.5 \times$ SSC, $0.01 \%$ SDS, and $0.06 \times$ SSC for 5 min each. The slides were centrifuged at $800 \mathrm{rpm}$ for $2 \mathrm{~min}$ to dry before scanning.

\section{Array scanning and data analysis}

The arrays were scanned with a GenePix 4000A scanner (Axon Instruments, Foster City, CA) at a $10 \mu \mathrm{m}$ resolution. The photo multiplier voltage settings were varied to obtain the maximum signal intensities with $<1 \%$ probe saturation. The color images were formed by assigning the SON intensity in red and the hypothalamic reference intensity in green (Fig. 3). The resulting images were analyzed using IPLab (Scanalytics, Fairfax, VA) and ArraySuite (National Human Genome Research Institute, $\mathrm{NIH}$, Bethesda, $\mathrm{MD}$ ) software, and the ratios of the red over the green intensity for all targets were determined. Calibrated ratios were obtained by a normalization method based on the ratio statistics (Chen et al., 1997, 2002), and elements with ratios $>2$ or $<0.5$ were considered to represent differentially expressed genes in the SON versus hypothalamic reference. To determine the reliability of each ratio measurement, a set of quality indicators were used, as follows: (1) association of sufficiently 

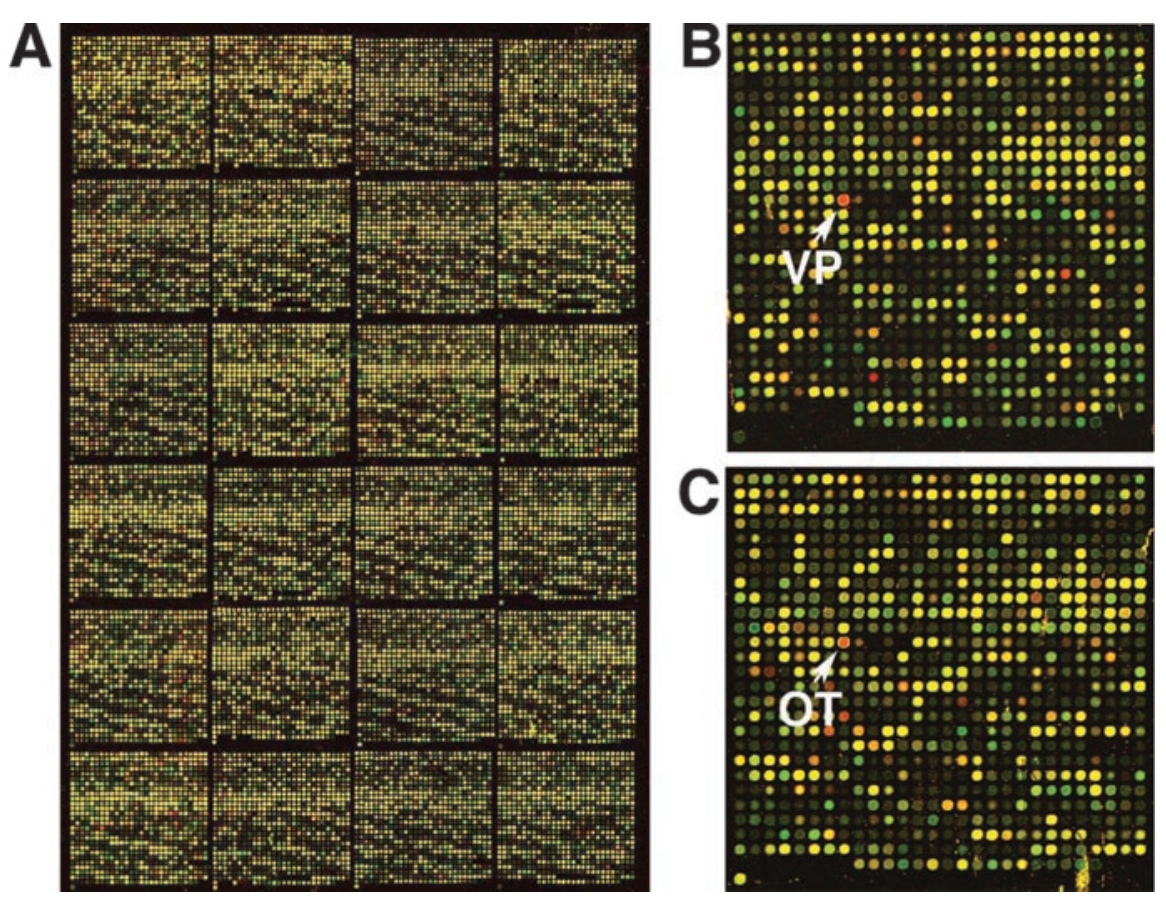

Figure 3. Scanned images of an Mm36kd2 series mouse DNA array hybridized with (y3-labeled (shown as a green signal) or Cy5-labeled (shown as a red signal) cDNA probes, which were generated from amplified rat hypothalamus reference and lasermicrodissected rat SON RNA, respectively. $A$, An image of half of the array is shown. The number of genes that showed a signal more than average background plus 3 SDs $(\sim 60)$ is 33,599 genes (95\% occupancy) for the SON-derived cDNA and 34,412 genes ( $97 \%$ occupancy) for the hypothalamus reference-derived cDNA. B, C, Higher-power views of individual panels on the array are shown including the VP $(B)$ and $0 \mathrm{~T}(C)$ target $C D N A s$. The arrows indicate the printed spot for the VP and OT genes. The red signal indicates genes that are expressed relatively more in the SON compared with the total hypothalamus, and the green signal indicates genes that are expressed relatively more in the hypothalamus compared with the SON. Yellow indicates genes that are approximately equivalently expressed in both of the tissues.

large numbers of pixels with the element; (2) flat local background; (3) uniform signal consistency within the target area; and (4) unsaturation of the majority of the signal pixels. Based on these indicators, a quality rank (Q) was measured ranging from 1 to 0 , and genes with a Q score $<0.1$ were excluded from our analysis. A detailed description of this procedure was described previously (Chen et al., 1997, 2002). Also, genes that showed intensity $<250$ (which is four times the average background plus 3 SDs of the arrays in this experiment) in the red (SON) channel were excluded from the analysis. All data points were done in triplicate or more. Previous "self-on-self" control experiments using this aminemodified indirect labeling method gave high correlation coefficients (Xiang et al., 2002). The data indicated that the relative expression ratios obtained from these comparisons are reproducible and do not show sequence or dye bias.

\section{In situ hybridization histochemistry}

In this study, we used a quantitative in situ hybridization histochemistry (ISHH) protocol described previously (Young et al., 1986), with minor variations. The rat VP probe was a $229 \mathrm{bp}$ fragment of the rat VP gene subcloned into pGEM-32 (Young et al., 1986). T7 and SP6 primers were used to PCR amplify the fragment, and the resulting PCR product was used as a template for the riboprobe synthesis. Plasmids contained selected expressed clones on the array that were studied by ISHH. First, we sequenced the plasmid to confirm the annotation. Then, these were PCR amplified using either T7 and a T3 primer [for Riken cDNA 2210012L08 gene; guanine nucleotide binding protein, $\alpha$ stimulating (GNAS); and Zinc finger 312] or a gene-specific primer sequence conjugated to a T7 or T3 primer sequence [for opsin, C1q domain containing 1 (C1q), expressed sequence tag (EST) similar to FLJ20037, glutathione peroxidase 3 , eukaryotic translation elongation factor $1 \alpha 2$, calreticulin (Calr), Rho GDP dissociation inhibitor (GDI) $\beta$, LIM only 4, PIPPIN, and putative homeodomain transcription factor] depending on the size of the insert. See Table 1 for PCR primer design and length of encompassing region in the clone. Each PCR product was used to obtain both sense and the antisense probes. Hybridization of each sense probe was performed as a negative control. The length of the resulting PCR product ranged from 500 to $600 \mathrm{bp}$ and was used as a template for the labeling. Riboprobe synthesis was performed using $30-40 \mathrm{ng}$ of the PCR product and $50 \mu \mathrm{Ci}$ of $\left[\alpha^{-}{ }^{35} \mathrm{~S}\right]-$ uridine $5^{\prime}$-triphosphate (UTP; Perkin-Elmer Life Sciences, Boston, MA), 10 mm DTT, along with the MAXIscript in vitro transcription kit (Ambion, Austin, TX).

Serial $10 \mu \mathrm{m}$ brain sections were cut on a cryostat and placed onto poly-L-lysine-coated slides (Fisher Scientific, Newark, DE), dried on a slide warmer for $10-30 \mathrm{~min}$ at $37^{\circ} \mathrm{C}$, and then stored at $-80^{\circ} \mathrm{C}$. Before hybridization, the sections were fixed in $4 \%$ formaldehyde for $10 \mathrm{~min}$ at room temperature, rinsed once and washed twice for $5 \mathrm{~min}$ in $1 \times \mathrm{PBS}$, put into $0.1 \mathrm{M}$ triethanolamine- $\mathrm{HCl}, \mathrm{pH} 8.0$, containing $0.25 \%$ acetic anhydride for $10 \mathrm{~min}$ at room temperature, rinsed with $2 \times$ SSC buffer and transferred through graded ethanol (75-100\%), and then air dried. Hybridization was performed in an $80 \mu \mathrm{l}$ hybridization solution (20 mu Tris-Cl, pH 7.4, 1 mm EDTA, pH 8.0, $300 \mathrm{~mm} \mathrm{NaCl} 50 \%$ formamide, $10 \%$ dextran sulfate, $1 \times$ Denhardt's solution, 100 $\mu \mathrm{g} / \mathrm{ml}$ salmon sperm DNA, $250 \mu \mathrm{g} / \mathrm{ml}$ yeast total RNA, $250 \mu \mathrm{g} / \mathrm{ml}$ yeast tRNA, $0.0625 \%$ SDS, and $0.0625 \%$ sodium thiosulfate) containing $10^{6} \mathrm{cpm}$ denatured $\mathrm{S}^{35}$-labeled riboprobe. After an overnight hybridization at $55^{\circ} \mathrm{C}$, the sections were washed four times in $4 \times$ SSC, incubated with TNE buffer $(10 \mathrm{~mm}$ Tris-Cl, $\mathrm{pH} 8.0,0.5 \mathrm{~m} \mathrm{NaCl}$, and $0.25 \mathrm{~mm}$ EDTA, pH8.0) containing $20 \mu \mathrm{g} / \mathrm{ml}$ ribonuclease A for $30 \mathrm{~min}$ at $37^{\circ} \mathrm{C}$, and then washed twice in $2 \times$ SSC, once in $1 \times$ and $0.5 \times$ SSC at room temperature, and twice in $0.1 \times \mathrm{SSC}$ at $65^{\circ} \mathrm{C}$. The sections were rinsed in graded ethanol solutions and then air dried. Finally, the sections were apposed to a low-energy storage phosphor screen (Amersham Biosciences) for 1-14 d and developed using a phosphorimager (Storm 860; Amersham Biosciences).

To evaluate the levels of mRNA in the supraoptic nuclei (Herman et al., 1991), the average densities and unit areas per SON of phosphor screen was measured in the sections from each rat bilaterally using the Image Quant software (version 5.2; Amersham Biosciences). Statistical significance of differences between groups was calculated by Student's $t$ test. Differences between groups were considered statistically significant when $p$ values were $<0.05$. Experiments were repeated on four animals, and results are expressed as mean \pm SEM.

For double-label ISHH, digoxigenin (DIG)-labeled VP or OT antisense riboprobes and ${ }^{35}$ S-labeled antisense riboprobes of the novel genes were cohybridized to identify whether the genes we found on the array were VP or OT specific. DIG labeling was done per the manufacturer's instructions (Roche Diagnostics, Indianapolis, IN) using PCR-amplified VP (30 ng) and OT (100 ng) sequences as templates (see Table 1 for details of the primer design). Overnight hybridization at $55^{\circ} \mathrm{C}$ was done using a $10^{6} \mathrm{cpm}{ }^{35}$ S-labeled antisense riboprobe and $1 \mu \mathrm{l}$ of the $50 \mu \mathrm{l}$ purified DIG-labeled antisense riboprobe per slide in a total of $80 \mu \mathrm{l}$ of hybridization solution (same as the hybridization solution used in a single ISHH hybridization). Then, the slides were washed as in the singleprobe hybridization method, processed for the DIG labeling probe by incubating in anti-DIG-AP (1:2000; Roche Diagnostics) made in $1 \times$ TBS $(0.1 \mathrm{M}$ Tris-Cl, pH7.5, fand $150 \mathrm{~mm} \mathrm{NaCl})$ and $5 \%$ normal goat serum (Vector Laboratories, Burlingame, CA) at $37^{\circ} \mathrm{C}$ for $5 \mathrm{hr}$, and developed with $0.33 \mathrm{mg} / \mathrm{ml}$ nitro blue tetrazolium chloride $/ 0.165 \mathrm{mg} / \mathrm{ml} 5$-bromo4-chloro-3-indolyphosphate (BCIP/NBT combo from Invitrogen, Carls- 
Table 1. Primer design and sequence information for the riboprobes used in the ISHH analysis

\begin{tabular}{|c|c|c|c|c|}
\hline Gene name & Size (bp) & Primer $^{a}$ & Accession number & Region of PCR product \\
\hline \multirow[t]{2}{*}{ Vasopressin } & \multirow[t]{2}{*}{228} & GCGCGTAATACGACTCACTATAGGG (T7) & \multirow[t]{2}{*}{ NM_016992 } & \multirow[t]{2}{*}{$344-588$} \\
\hline & & CATACGATTTAGGTGACACTATAG (SP6) & & \\
\hline \multirow[t]{2}{*}{ 0xytocin } & \multirow[t]{2}{*}{487} & GCGCGTAATACGACTCACTATAGGG (T7) & \multirow[t]{2}{*}{ X59496 } & \multirow[t]{2}{*}{$2303-2775$} \\
\hline & & CATACGATTTAGGTGACACTATAG (SP6) & & \\
\hline \multirow[t]{2}{*}{ C1q domain containing 1} & \multirow[t]{2}{*}{622} & CGCGCAATTAACCCTCACTAAAGGTACCACTGTATGTCAACCTG & \multirow[t]{2}{*}{ XM_132976 } & \multirow[t]{2}{*}{$3082-3615$} \\
\hline & & GCGCGTAATACGACTCACTATAGGGATTGAGGCACAACGAGGCAT & & \\
\hline \multirow[t]{2}{*}{ EST similar to FLJ20037 } & \multirow[t]{2}{*}{586} & CGCGCAATTAACCCTCACTAAAGGATGGGTGAGAGTGTCTATGG & \multirow[t]{2}{*}{ XM_21728 } & \multirow[t]{2}{*}{$1155-1652$} \\
\hline & & GCGCGTAATACGACTCACTATAGGGACCAAGTAGAGTATGTCTGC & & \\
\hline \multirow[t]{2}{*}{ Glutathione peroxidase 3} & \multirow[t]{2}{*}{602} & CGCGCAATTAACCCTCACTAAAGGAGTCTCAAGTATGTTCGACC & \multirow[t]{2}{*}{ BC003339 } & \multirow[t]{2}{*}{$376-889$} \\
\hline & & GCGCGTAATACGACTCACTATAGGGTGGGACAATTGTCACGTGTC & & \\
\hline \multirow[t]{2}{*}{ Riken cDNA 2210012L08 } & \multirow[t]{2}{*}{576} & GCGCGTAATACGACTCACTATAGGG (T7) & \multirow[t]{2}{*}{ AK008716 } & \multirow[t]{2}{*}{$1125-1553$} \\
\hline & & CGCGCAATTAACCCTCACTAAAGG (T3) & & \\
\hline \multirow[t]{2}{*}{ Zinc finger protein 312} & \multirow[t]{2}{*}{639} & GCGCGTAATACGACTCACTATAGGG (T7) & \multirow[t]{2}{*}{ NM_080433 } & \multirow[t]{2}{*}{$1469-2058$} \\
\hline & & CGCGCAATTAACCCTCACTAAAGG (T3) & & \\
\hline \multirow[t]{2}{*}{ Opsin (encephalopsin) } & \multirow[t]{2}{*}{645} & CGCGCAATTAACCCTCACTAAAGGACAGAAGCAGCGCATCTAAG & \multirow[t]{2}{*}{ AC094917 } & $32175-32731$ \\
\hline & & GCGCGTAATACGACTCACTATAGGGTGAAGCCCTCGCAGCTGTAC & & \\
\hline Guanine nucleotide binding protein, $\alpha$ stimulating & 524 & GCGCGTAATACGACTCACTATAGGG (T7) & AF116268 & $2017-2492$ \\
\hline & & CGCGCAATTAACCCTCACTAAAGG (T3) & & \\
\hline Eukaryotic translation elongation factor $1 \alpha 2$ & 594 & CGCGCAATTAACCCTCACTAAAGGATGGTGACAACATGCTGGAG & NM_007906 & $723-1228$ \\
\hline & & GCGCGTAATACGACTCACTATAGGGCGTGTGACAGTCGATGACTG & & \\
\hline Calreticulin & 594 & CGCGCAATTAACCCTCACTAAAGGAGCTGTAGAGGCCACACCAC & NM_007591 & 1312-1816 \\
\hline & & GCGCGTAATACGACTCACTATAGGGAGCTGTGCTAGAACTGGCTG & & \\
\hline Rho GDP dissociation inhibitor (GDI) $\beta$ & 593 & CGCGCAATTAACCCTCACTAAAGGTGTATGTGACAGTGCACCAG & BC031763 & $250-753$ \\
\hline & & GCGCGTAATACGACTCACTATAGGGTGACAGAGAAAGGGCCTAGC & & \\
\hline LIM only 4 & 561 & CGCGCAATTAACCCTCACTAAAGGATGGACAGCTACTGGCATAG & NM_010723 & $184-655$ \\
\hline & & GCGCGTAATACGACTCACTATAGGGAGGTGACTGGTCTACTGCAG & & \\
\hline PIPPIN (cold shock protein) & 553 & CGCGCAATTAACCCTCACTAAAGGATGTGAGCACAGATAGCCAG & АК028916 & $1810-2273$ \\
\hline & & GCGCGTAATACGACTCACTATAGGGAGTTTCTGACTTGGCGCTGC & & \\
\hline Putative homeodomain transcription factor & 608 & CGCGCAATTAACCCTCACTAAAGGAGCTGTTAAAGGAGCTGGAC & BC060177 & $2563-3082$ \\
\hline & & GCGCGTAATACGACTCACTATAGGGAGACAGTTGCGTCATGCTTC & & \\
\hline
\end{tabular}

${ }^{a}$ Bold letters indicate the universal primer site. Top row, Forward primer; bottom row, reverse primer.

${ }^{b}$ The opsin clone obtained from the array was found to be the $3^{\prime}$ untranslated region ( $3^{\prime}$ UTR) of mouse opsin by sequence analysis (GenBank accession number AF14021; nt 1339-1721). We cloned the rat opsin $3^{\prime}$ UTR sequence that encompasses the sequence region of this clone and used it as the template for the riboprobe. The GenBank accession number indicates the rat genomic sequence that applies to the $3^{\prime} \mathrm{UTR}$ sequence of the rat opsin, which was predicted by a homology search of the rat and mouse sequences.

bad, CA) and Levamisole (Vector Laboratories) in $0.1 \mathrm{~m}$ Tris-Cl, pH 9.5, $0.1 \mathrm{M} \mathrm{NaCl}$, and $50 \mathrm{mM} \mathrm{MgCl}_{2}$ for $30 \mathrm{~min}$ to $1 \mathrm{hr}$ at room temperature. The slides were coated with Ilford K.5D nuclear emulsion (Polysciences, Warrington, PA) and developed using D-19 (Eastman Kodak, Rochester, $\mathrm{NY}$ ) after 7-60 d of exposure when the grains were visible. The slides were mounted with Cytoseal 60 mount medium and coverslipped.

\section{Results}

Representations of SON and hypothalamic RNAs on the microarray

RNA isolated from laser-microdissected supraoptic nuclei (Fig. $1 B$ ) and comparable levels (150 ng) of RNA from whole hypothalami from male rats used as a reference in all the experiments underwent two rounds of linear amplification using a T7-based in vitro transcription method (see Materials and Methods). In a preliminary study, we found that to obtain a sufficient amount of amplified RNA to generate probes for microarray analysis, two rounds of amplification from the SON samples were necessary. The average amplification was 17,424-fold for the SON and 19,504-fold for the hypothalamus after two rounds of amplification. The SON cDNAs were labeled with Cy5 (and assigned a red fluorescence signal when the image was processed), and the hypothalamic reference cDNAs were labeled with Cy3 (and assigned a green fluorescence signal when the image was processed). Fluorescent probes generated from the amplified RNA samples were hybridized on a microarray containing 35,319 genes (Fig. 3A). After hybridization, slides were scanned, independent images of the hypothalamic reference and SON channels were generated, and fluorescence intensities were calculated. Af- ter calculation, normalization was performed to adjust differences in labeling and detection efficiencies for the fluorescent labels from the two samples examined in the assay [normalization methods are reviewed elsewhere (Quackenbush, 2002)]. The number of elements with signals $>3$ SD above the average background ( $\sim 60)$ was 33,599 genes (i.e., $95 \%$ of the genes on the array) for the SON-derived cDNA and 34,412 genes (i.e., 97\% of the genes on the array) for the hypothalamus-derived reference cDNA. The high occupancy rates show that both the hypothalamic and the SON samples have comparable and very high representations of genes on the microarray.

To identify genes that are preferentially expressed in the SON, we used the SON/hypothalamus expression ratio. The SON/hypothalamus expression ratio is the normalized value of the expression level for a particular gene in the SON sample, divided by the normalized value of this gene in the hypothalamic reference sample (see Materials and Methods). Among the 34,972 genes that passed our quality criteria for hybridization (see Materials and Methods), 1385 genes (0.040\%), including the VP (Fig. 3B) and OT (Fig. $3 C$ ) genes, showed more than a twofold greater expression in the SON relative to the whole hypothalamus (see Table 2 and supplemental Tables 1S-3S, available at www. jneurosci.org/cgi/content/full/24/32/7174/DC1), and 1237 genes $(0.035 \%)$ showed more than twofold greater expression in the whole hypothalamus relative to the SON. Among the latter were various glial-specific genes, such as myelin basic protein (see supplemental Table 4S, available at www.jneurosci.org/cgi/content/ 
Table 2. Genes on the array that are preferentially expressed in the SON compared with the total hypothalamus (with expression ratios $\geq 3.4$ )

\begin{tabular}{|c|c|c|}
\hline Clone identification & Gene name & SON/hypothalamus RNA \\
\hline \multicolumn{3}{|c|}{ Neuropeptides and secretion-related genes } \\
\hline$a$ & Vasopressin & $43.9 \pm 5.24$ \\
\hline Al852818 & Prodynorphin & $16.7 \pm 0.44$ \\
\hline$a$ & Oxytocin & $9.4 \pm 0.17$ \\
\hline C78062 & Signal sequence receptor $\delta$ & $5.3 \pm 0.02$ \\
\hline C78001 & Adaptor protein complex AP-2, $\alpha 2$ subunit & $3.8 \pm 0.11$ \\
\hline Al843138 & Synaptotagmin 4 & $3.8 \pm 0.13$ \\
\hline Al851833 & Endoplasmic reticulum protein 29 & $3.8 \pm 0.10$ \\
\hline \multicolumn{3}{|c|}{ Transcription- and translation-related genes } \\
\hline Al852056 & Zinc finger protein 312 & $9.7 \pm 0.67$ \\
\hline Al847977 & Proteasome (prosome, macropain) 265 subunit, non-ATPase, 10 & $8.5 \pm 0.24$ \\
\hline Al841269 & Tumor protein p53-inducible protein 11 & $8.1 \pm 0.56$ \\
\hline BE987826 & Ribonuclease P1 & $7.0 \pm 3.25$ \\
\hline Al836090 & 285 ribosomal protein S26, mitochondrial precursor (MRP-S26) (50T-EST protein) & $6.2 \pm 0.14$ \\
\hline Al836878 & Necdin & $5.4 \pm 0.16$ \\
\hline AW555415 & General transcription factor IIA (TF IIA) & $5.1 \pm 0.27$ \\
\hline Al845507 & Numb gene homolog (Drosophila) & $4.7 \pm 0.19$ \\
\hline AW048967 & SRY-box containing gene 17 (Sox 17) & $4.6 \pm 0.11$ \\
\hline Al847764 & Defender against cell death 1 & $4.5 \pm 0.10$ \\
\hline Al836186 & Ribosomal protein $\mathrm{L} 3$ & $4.2 \pm 0.08$ \\
\hline Al849592 & ELAV (embryonic lethal, abnormal vision, Drosophila)-like 4 (Hu antigen D) & $4.1 \pm 0.06$ \\
\hline AW552980 & Eukaryotic translation elongation factor $1 \alpha 1$ & $4.1 \pm 0.07$ \\
\hline AU017980 & DnaJ (Hsp40) homolog, subfamily C, member 3 & $3.9 \pm 0.07$ \\
\hline AW548907 & Ribosomal protein 10 & $3.8 \pm 0.08$ \\
\hline Al845516 & Transcription factor E2A & $3.8 \pm 0.32$ \\
\hline AA408475 & Ribosomal protein L13a & $3.6 \pm 0.15$ \\
\hline AU021016 & Ribosomal protein $\mathrm{L} 6$ & $3.5 \pm 0.19$ \\
\hline Al843614 & Retinol binding protein 1 , cellular & $3.4 \pm 0.07$ \\
\hline \multicolumn{3}{|c|}{ Signal transduction-related genes and receptors } \\
\hline AW492784 & Opsin (encephalopsin) & $6.2 \pm 0.33$ \\
\hline Al842162 & Guanine nucleotide binding protein, $\alpha$ stimulating & $5.4 \pm 0.30$ \\
\hline Al836396 & Protein tyrosine phosphatase, receptor-type $\mathrm{N}$ & $5.0 \pm 0.25$ \\
\hline AW546949 & Guanylate cyclase 1 , soluble, $\alpha 3$ & $5.0 \pm 0.11$ \\
\hline AW049244 & Mus musculus olfactory receptor 31 (Olfr31) & $4.9 \pm 0.06$ \\
\hline AW538857 & Hormonally upregulated Neu-associated kinase & $4.4 \pm 0.08$ \\
\hline Al838302 & Cd63 antigen & $4.2 \pm 0.06$ \\
\hline AW122640 & Neuregulin 1 & $4.1 \pm 0.01$ \\
\hline Al841688 & Jagged 2 & $4.0 \pm 0.12$ \\
\hline Al854279 & DOC2/DAB2 interactive protein & $4.0 \pm 0.25$ \\
\hline AW551028 & M. musculus Vav2 oncogene & $4.0 \pm 0.19$ \\
\hline Al834829 & PKE (serine/threonine kinase 32C) protein kinase & $3.9 \pm 0.22$ \\
\hline Al851231 & $\mathrm{GABA}_{\mathrm{A}}$ receptor, subunit $\gamma 2$ & $3.9 \pm 0.23$ \\
\hline Al842572 & Rho, GDP dissociation inhibitor (GDI) $\beta$ & $3.4 \pm 0.07$ \\
\hline \multicolumn{3}{|c|}{ Channels and Ca-binding proteins } \\
\hline Al849182 & M. musculus secretagogin, EF-hand calcium binding protein & $7.2 \pm 0.28$ \\
\hline AW045201 & Gene cell growth regulator with EF-hand domain & $6.1 \pm 0.32$ \\
\hline Al849795 & Nucleobindin 2 & $5.2 \pm 0.29$ \\
\hline AW061097 & Calcium binding protein 140 (Cab140) & $4.3 \pm 0.17$ \\
\hline AW545345 & Calreticulin & $3.8 \pm 0.32$ \\
\hline AW046406 & Potassium voltage-gated channel, subfamily H (eag-related), member 1 & $3.8 \pm 0.22$ \\
\hline \multicolumn{3}{|l|}{ Cytoskeleton } \\
\hline Al839417 & Moesin & $6.2 \pm 0.90$ \\
\hline BE983842 & KIF13A (M. musculus) & $4.6 \pm 0.10$ \\
\hline Al849805 & Staufen (RNA-binding protein) homolog 1 (Drosophila) & $4.6 \pm 0.09$ \\
\hline \multicolumn{3}{|c|}{ Metabolism-related genes } \\
\hline Al848954 & M. musculus vesicle amine transport protein 1 homolog & $7.0 \pm 0.33$ \\
\hline Al839365 & Phospholipase D3 & $6.2 \pm 0.15$ \\
\hline Al839368 & Carbonyl reductase 1 & $4.7 \pm 0.31$ \\
\hline Al848985 & Alanyl (membrane) aminopeptidase & $4.6 \pm 0.21$ \\
\hline Al852144 & Pre-B-cell colony-enhancing factor & $3.7 \pm 0.07$ \\
\hline
\end{tabular}


Table 2. Continued

\begin{tabular}{|c|c|c|}
\hline Clone identification & Gene name & SON/hypothalamus RNA \\
\hline \multicolumn{3}{|l|}{ Miscellaneous genes } \\
\hline BE946020 & C1q domain containing 1 & $24.6 \pm 0.98$ \\
\hline AW122588 & ESTs, similar to FLJ20037 & $10.6 \pm 0.50$ \\
\hline AW550656 & Glutathione peroxidase 3 & $10.0 \pm 0.72$ \\
\hline BE992185 & RIKEN cDNA 2210012L08 & $10.0 \pm 0.71$ \\
\hline Al847787 & ESTs, alchohol dehydrogenase containing & $9.0 \pm 0.47$ \\
\hline BF465855 & ESTs, $5^{\prime}$ of steroid $5 \alpha$-reductase 2 -like & $8.8 \pm 0.84$ \\
\hline Al843316 & Castration induced prostatic apoptosis related protein-1 (CIPAR-1) homolog & $6.5 \pm 0.16$ \\
\hline AW554580 & CD151 antigen & $5.3 \pm 0.29$ \\
\hline AW060584 & Dlgh1 homolog (chapsyn-110) & $4.9 \pm 0.35$ \\
\hline Al836238 & M. musculus coatomer protein complex, subunit $\gamma 2$, antisense 2 & $4.7 \pm 0.34$ \\
\hline AW544525 & Solute carrier family 35 (UDP-galactose transporter), member 2 & $4.4 \pm 0.29$ \\
\hline Al852097 & 4-Nitrophenylphosphatase domain and non-neuronal SNAP25-like protein homolog 1 & $4.2 \pm 0.31$ \\
\hline Al846348 & Hypoxia-induced gene 1 & $3.9 \pm 0.12$ \\
\hline AW553447 & Serine (or cysteine) proteinase inhibitor, clade B (ovalbumin), member 6 & $3.9 \pm 0.18$ \\
\hline AU042923 & ELOVL family member 5 , elongation of long chain fatty acids (yeast) $9 \mathrm{E} 1$ & $3.9 \pm 0.06$ \\
\hline AW547239 & Signal sequence receptor, $\alpha$ (Ssr1) & $3.8 \pm 0.04$ \\
\hline AU040950 & Mammalian ependymin-related protein-2 (MERP2) gene, complete cds (cDNA sequence) & $3.8 \pm 0.22$ \\
\hline Al844264 & Proteasome (prosome, macropain) subunit, $\beta$ type 4 & $3.7 \pm 0.21$ \\
\hline Al845618 & Immunosuperfamily protein 4 & $3.7 \pm 0.09$ \\
\hline AW122994 & Contactin-associated protein 4 & $3.6 \pm 0.15$ \\
\hline Al838699 & T-cell immunomodulatory protein & $3.6 \pm 0.25$ \\
\hline AW049970 & M. musculus similar to F-box only protein 10 & $3.5 \pm 0.26$ \\
\hline AW555026 & Protein $S(\alpha)$ & $3.4 \pm 0.14$ \\
\hline
\end{tabular}

The genes shown are expressed at 3.4-fold greater levels in the SON than in the total hypothalamus and represent sequences that are ESTs annotated in either BLAST (Basic Local Alignment Search Tool) or Riken database searches. ESTs identified by sequence can be found in supplemental Table $1 S$ (available at www.jneurosci.org/cgi/content/full/24/32/7174/DC1). Values are shown as the average ratio (SON intensity divided by the hypothalamus intensity) \pm SEM. Gene expression ratios were determined by comparative analysis of two separate experimental groups of laser-captured control rat SONs ( $n=3 /$ group) against a rat hypothalamus reference ( $n=10)$, with triplicate or quadriplicate array hybridization for each. Data were used only for genes that met several criteria (see Materials and Methods) including fold changes $\geq 3.4$ and the filtering of the low-quality ratio spots. The GenBank accession number, annotation and the category of the annotations are indicated for each gene. Categories were determined by Pubmatrix (http:// pubmatrix.grc.nia.nih.gov/) search. Results were reproduced by two independent probe sets.

${ }^{a}$ The VP and OT DNAs on the array were PCR amplified from plasmids containing rat VP and OT genes (see Materials and Methods).

full/24/32/7174/DC1). The average Pearson correlation coefficient for replicate arrays was 0.86 .

To establish criteria for "preferential expression" in the SON, we first analyzed expression ratios for ubiquitous "housekeeping" genes, such as actin, tubulin, etc. The mean expression ratios ( \pm SEM) of $\beta$-actin, $\alpha$-tubulin, $\beta$-tubulin, and glyceraldehyde- 3 phosphate dehydrogenase were $1.07 \pm 0.04(n=8), 1.10 \pm 0.05$ $(n=8), 1.49 \pm 0.07(n=3)$, and $1.50 \pm 0.04(n=4)$, respectively, where $n$ is the number of distinct elements (DNA sequences) on the array. On this basis, we defined that an expression ratio $<2$ reflected essentially equivalent levels of the expression of a gene in both tissues, and our subsequent analysis focused on genes with expression ratios between 2 and 3.4, between 3.4 and 9.4, and $\geq 9.4$. Although genes with expression ratios from 2 to 3.4 are likely to be preferentially expressed in the SON, we did not attempt to validate this inference by ISHH, and hence we only present this list of these genes in supplemental Tables 1S-3S (available at www.jneurosci.org/cgi/content/full/ 24/32/7174/DC1) for interested readers. An expression ratio of 3.4 represented our threshold for preferential expression in the SON that was validated by ISHH (Fig. $4 F$ ). Expression ratios $\geq 9.4$ include the OT and VP genes (Table 2), which are known to be very highly and selectively expressed in the SON.

\section{ISHH validation of genes determined to be preferentially expressed in the SON}

To determine whether the expression ratio measured by microarray analysis truly reflected preferential gene expression in the SON, a preliminary single-label ISHH analysis was performed on 20 genes, the expression ratios of which ranged from 0.6 to 44.0. This ISHH analysis was used to determine which clones could be detected in the SON and how predictive the expression ratio was with regard to preferential expression of a given gene in the SON. For this purpose, we used coronal hypothalamic frozen sections from normal male rats. All of these transcripts could be detected in the SON by ISHH, but the extent of hybridization in other regions of the brain greatly varied among mRNAs. Examples of the data obtained are shown in Figure 4 . When the expression ratio was $\geq 3.4$, an intense and clearly preferential expression was observed in the SON (Fig. 4A-F). When the expression ratio was $\leq 1.0$ (Fig. 4G,H), there was detectable hybridization in the SON, but hybridization was comparable or greater in other regions of the hypothalamus.

Thus, we determined that an expression ratio $\geq 3.4$ consistently reflected the preferential expression of genes in the SON. Table 2 shows a list of 77 genes with expression ratios $\geq 3.4$. These genes have a wide variety of functions in the MCNs and are classified by presumed function in Table 2 . The 54 other genes that showed an expression ratio $\geq 3.4$ were unclassified ESTs, and these are presented in supplemental Table 1S (available at www. jneurosci.org/cgi/content/full/24/32/7174/DC1). Genes with moderate expression ratios (2-3.4) are presented in supplemental Tables 2S and 3S (available at www.jneurosci.org/cgi/content/ full/24/32/7174/DC1), which show both functionally classified genes and unclassified ESTs, respectively. Finally, supplemental Table 4S (available at www.jneurosci.org/cgi/content/full/24/32/ $7174 / \mathrm{DC} 1)$ presents a list of 83 genes with fourfold lower expression in the SON than in the whole hypothalamus (i.e., where the expression ratio was $<0.25$ ).

\section{Osmotic regulation of preferentially expressed genes in the SON}

We also used ISHH analysis to determine whether various preferentially expressed genes are regulated by osmotic perturbations. For this analysis, we compared the expression level 


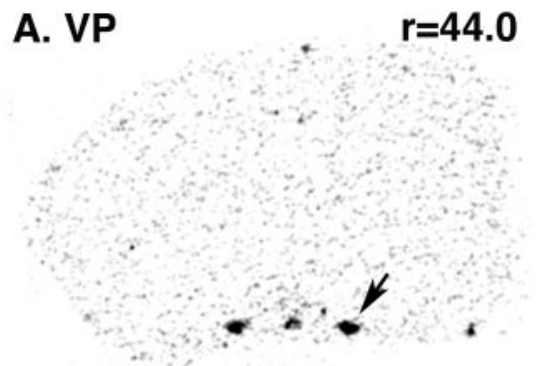

\section{B. C1q}

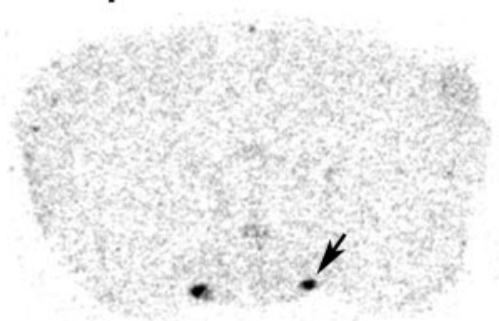

\section{ZFP 312}

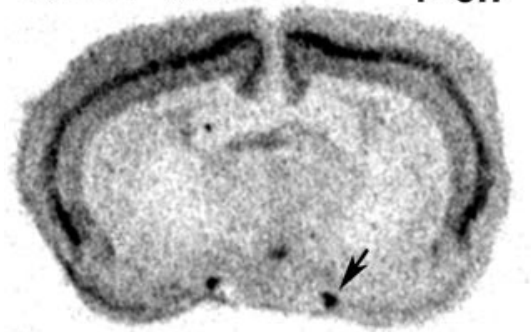

\section{Gpx 3}

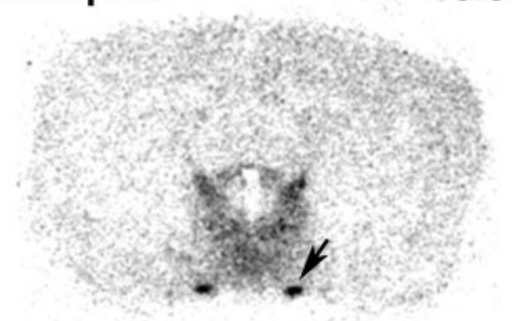

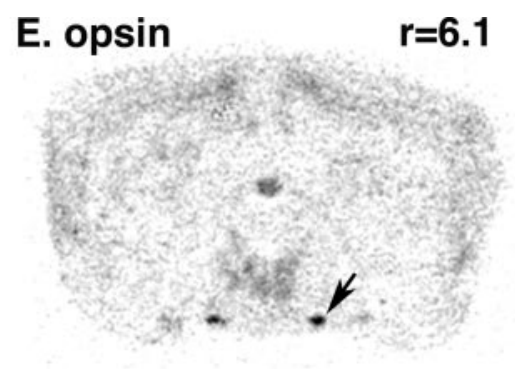

F. Rho GDI

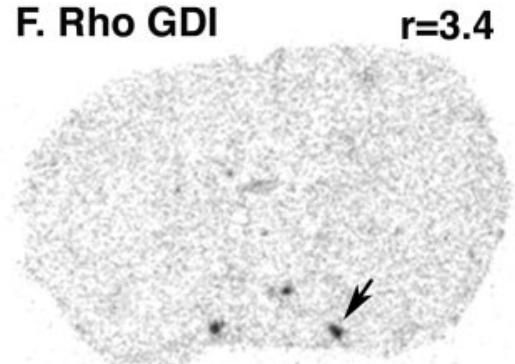

G. PIPPIN

$r=0.9$

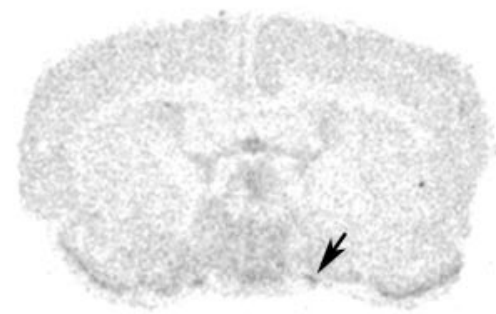

H. Lmo 4 $r=0.6$

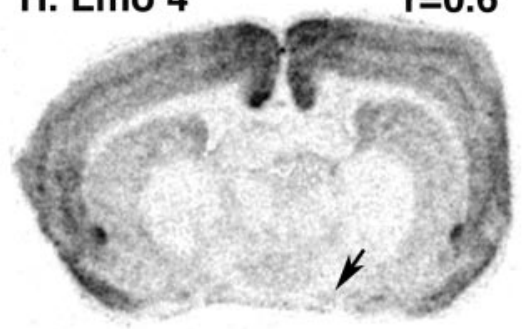

Figure 4. ISHH analysis of genes determined by quantitative microarray analysis to be expressed at higher levels in the SON compared with the hypothalamus (see Table 1). The SON/hypothalamus expression ratio for each gene that was obtained by microarray analysis is indicated at the top right of each panel. ISHH was performed on coronal sections through the SON of a control rat. C1q, C1q domain containing 1; ZFP 312, zinc finger protein 312; Gpx 3, glutathione peroxidase 3; opsin, encephalopsin; Rho GDI, GDP dissociation inhibitor $\beta$; PIPPIN, cold shock protein; Lmo 4, LIM only 4 . The arrows indicate the location of the SON.

of each gene in normal and hyperosmolar rats. Figure 5 illustrates the effect of chronic hyperosmolality on VP (Fig. 5A), C1q domain containing 1 gene (Fig. $5 B$ ), Rho GDP dissociation inhibitor $\beta$ (Fig. $5 C$ ), and encephalopsin (Fig. 5D) gene expression. Quantitative analysis of the changes in SON mRNA levels of the transcripts illustrated in Figure 5 showed a significant increase in gene expression in all of the mRNAs examined during the hyperosmolar condition (Fig. 6). Table 3 shows the changes in gene expression in hyperosmolar versus control conditions for VP and nine other genes with expression ratios $\geq 3$. 4 that we selected from Table 2 and for four genes with expression ratios $<3.4$. All of the clones in Table 3 had increases in mRNA levels during the hyperosmolar condition. Among these genes, $\mathrm{C} 1 \mathrm{q}$ domain containing 1 gene, Rho GDP dissociation inhibitor $\beta$, EST similar to FLJ20037, calreticulin, and encephalopsin had greater increases in ex- pression in the supraoptic nuclei of hyperosmolar rats than did the VP gene.

\section{OT- and VP-MCN-specific gene expression as evaluated by double-label ISHH}

Double-labeled ISHH was also used to determine whether selected examples of the preferentially expressed genes were differentially expressed in OT versus VP neurons in the rat SON (Fig. 7, Table 3). Figure 7 shows examples of the data from these experiments. The MCNs were visualized by the hybridization of either an OT or VP riboprobe labeled with DIG (shown as a brownish precipitate), and the riboprobes derived from the genes on the array (see Table 1) were radioactively labeled with ${ }^{35}$ S-UTP and visualized as autoradiographic grains (shown as pseudocolor red in the figure). Of the three genes shown in Figure 7, the results with GNAS (Fig. $7 A, B$ ) was typical of RNAs that were present at equivalent levels in the OT- and VP-MCNs, and C1q (Fig. $7 C, D$ ) and an EST similar to FLJ20037 (Fig. 7E, F) represent RNAs that are preferentially expressed in VPMCNs. The last column in Table 3 summarizes these double-label ISHH data. Of the eight genes studied, C1q, EST similar to FLJ20037, and the Riken cDNA 2210012L08 gene, all with expression ratios $\geq 10$, are preferentially expressed in VP-MCNs, and the other five were found in equivalent levels in OTand VP-MCNs. Surprisingly, none of the selected preferentially expressed genes were expressed predominantly in OT-MCNs.

\section{Discussion}

In this study, we used laser microdissection, T7-based RNA amplification, and DNA microarrays to characterize the gene expression profiles of OT- and VP-MCNs in the SON. We were particularly interested in identifying genes, other than OT and VP, that are preferentially expressed in the SON. The microarray data from this study are presented in the form of expression ratios (i.e., the ratio of the signal in the SON relative to the total hypothalamus). Most of the genes that were previously known to be expressed in the MCNs resided in the 2-3.4 expression ratio category (see supplemental Tables $2 \mathrm{~S}$ and $3 \mathrm{~S}$, available at www.jneurosci.org/cgi/content/full/24/ $32 / 7174 / \mathrm{DC} 1$ ) or had expression ratios $<2$ (data not shown). However, there is a wide variety of novel genes with expression ratios $\geq 3.4$ that were found in the SON (Tables 2 and supplemental Table 1S, available at www.jneurosci.org/cgi/content/full/24/32/7174/ DC1). Most notable are 19 genes related to transcription and translation (Table 2) and miscellaneous genes of unknown function (Table 2). It is in the latter category in which most of the genes with expression ratios $\geq 9.4$ were found.

Genes with expression ratios equal to or $>3.4$ are shown in 
Table 2 (annotated and organized according to presumed function) and in supplemental Table 1S (as unannotated ESTs; available at www.jneurosci.org/cgi/content/ full/24/32/7174/DC1). Some of these genes already known to be expressed in MCNs (Burbach et al., 2001) include OT, VP, prodynorphin and the GABA-A $\gamma 2$ receptor subunit (Table 2). Other genes that are known to be expressed in the MCNs are absent from Table 2 because they have expression ratios $<2$; these include cholecystokinin, enkephalin, cocaine-amphetamineregulated transcript, the $\mathrm{GABA}_{\mathrm{A}}$ receptor $\alpha 1$ and $\beta 2$ subunits, $G_{A B A_{B}}$ receptor 1 , several subtypes of AMPA (AMPA1, -2, -3, and -4), kainate (KA1, -2, and -5), NMDA (NMDA1, $-2 \mathrm{C},-2 \mathrm{D},-3 \mathrm{~B})$, and metabotropic (mGLUR3) receptors. Similarly, the relative paucity of neuropeptides and secretion-related genes in Table 2 is an expected consequence of using the neuroendocrine-rich hypothalamus as the reference tissue. A very low expression ratio for the AMPA-2 subunit of 0.18 (see supplemental Table 4S, available at www.jneurosci.org/ cgi/content/full/24/32/7174/DC1) supports the report that the functional AMPA receptor in the SON lacks this receptor subtype (Hollmann et al., 1991).

A relatively large number of genes with expression ratios $\geq 3.4$ were found in the transcription- and translation-related category (Table 2). This may be because of the high rates of peptide biosynthesis in the MCNs (Burbach et al., 2001). The highest expression ratio among the transcription factors was 9.7 for the zinc finger protein 312 (also known as forebrain embryonic zinc finger, $\mathrm{Fez}$ ). Zinc finger protein 312/Fez contains six C2H2-type zinc finger domains and is highly conserved in diverse species (Hashimoto et al., 2000; Matsuo-Takasaki et al., 2000; Yang et al., 2001; Levkowitz et al., 2003). Figure 4C shows that zinc finger protein 312 is robustly expressed in the SON and cortex (see also MatsuoTakasaki et al., 2000) and increases more than twofold during hyperosmolar conditions (Table 3 ). This is the first study to identify the zinc finger protein 312 as an osmotically regulated transfactor in the rat SON, and future experiments will be directed at its possible role in the osmotic regulation of OT and VP gene expression.

Other genes shown in Table 2 are generally or ubiquitously expressed genes (e.g., ribosomal proteins, translation elongation/ initiation factors, imprinted genes, etc.). Among these are general transcription factor IIA (Roeder, 1991; Cortes et al., 1992; Ma et al., 1996), transcription factor E2A (Murre et al., 1989; Melloul et al., 2002), Hu antigen D (Keene, 2001; Perrone-Bizzozero and Bolognani, 2002; Park-Lee et al., 2003), and Sox 17 (Kanai et al., 1996; Kanai-Azuma et al., 2002). It is interesting that these widely expressed, transcriptionally related gene products are preferentially expressed in the SON relative to the hypothalamus, with expression ratios ranging from 3.8 to 5.1 (Table 2), again likely

\section{control}
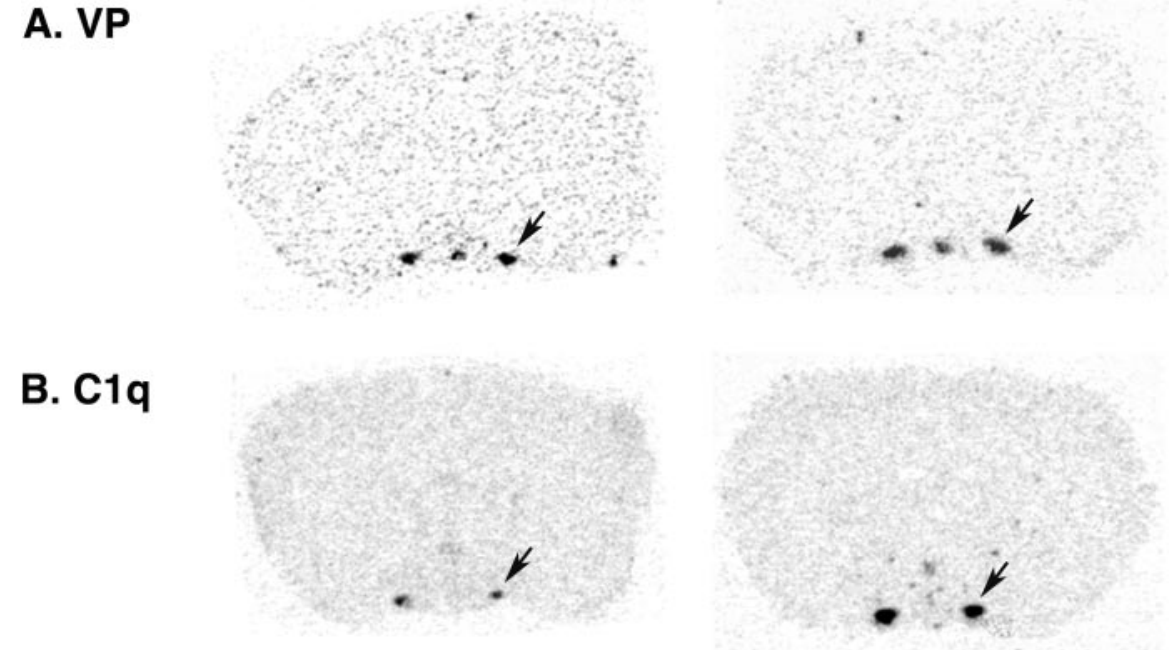

hyperosmolar
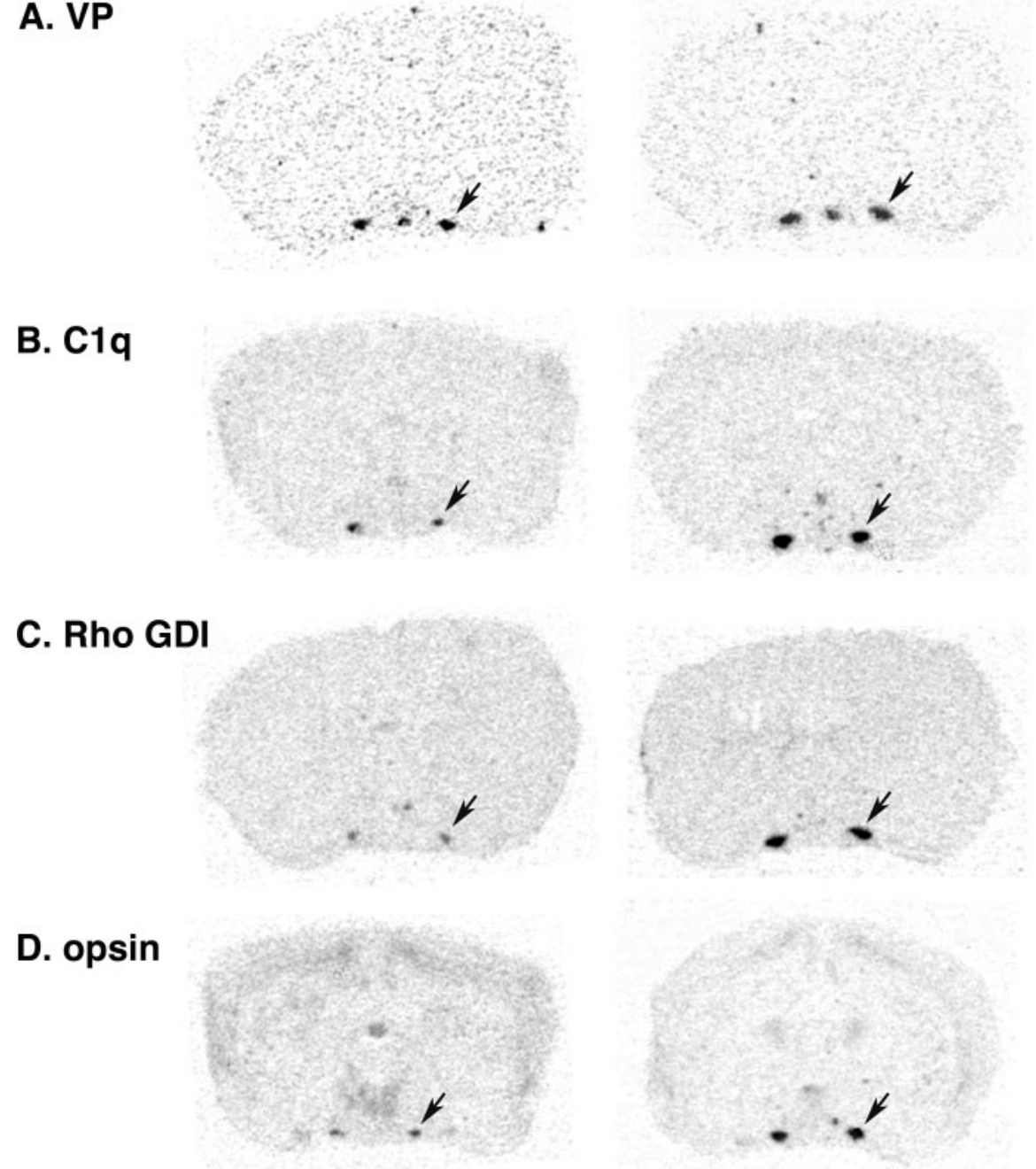

Figure 5. Illustrations of ISHH analysis of changes in the expression level of various high-ratio genes as a result of chronic four independent animal experiments. In this figure, the controls (also shown in Fig. 4A, $B, E, F$ ) were normalized to tissue background of the hyperosmolar rats (for quantitative ISHH analysis, see Fig. 6).

correlating with the high rates of transcription that occur in the SON (Burbach et al., 2001). There are a number of miscellaneous genes presented in Table 2 that are selectively expressed in the $\mathrm{SON}$, and these are highlighted in Table 3. The highest expression ratio in this group of genes is 24.6 for the C1q domain containing 1 gene. C1q domain containing 1 (also known as EEG-1) has been identified as a novel growth-related gene involved in hematopoetic differentiation and is also believed to also play a general role in terminal differentiation (Aerbajinai et al., 2004). This gene is of particular interest not only because it has an exceptionally high expression ratio, but also because its expression during chronic hyperosmolar conditions increases to $926 \%$ of control levels (Fig. 6 , Table 3). The results of double-label ISHH indicate that the C1q gene is primarily expressed in VP-MCNs (Fig. 7, Table 3).

Several other ESTs with high expression ratios in Table 3 have no significant annotations in the database, to date, but are also clearly of interest. These include EST similar to FLJ20037, with a ratio of 10.7, and Riken cDNA 2210012L08, with a ratio of 10.0. 

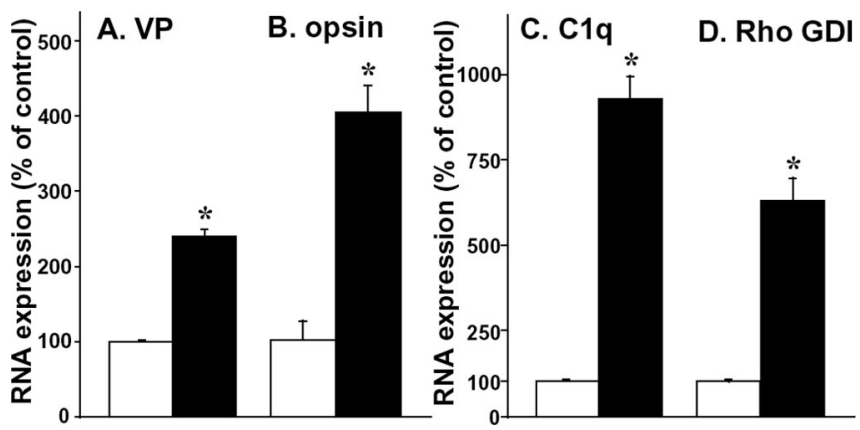

Figure 6. Quantitative ISHH data showing changes in mRNA levels in response to hyperosmolar conditions. mRNA levels are shown for VP $(A)$, encephalopsin (opsin) $(B), C$ ( $q$ domain containing 1 (C1q) (C), and GDP dissociation inhibitor $\beta$ (Rho GDI) (D). mRNA in control ( $\square$ ) and hyperosmolar $(\mathbf{\square})$ rats are shown. The data are averages from four rats. ${ }^{*} p<0.05$, compared with the control rat mRNA. Average values are shown as a percentage of the controls. Bars indicate the mean \pm SEM. Statistical significance of difference between groups was calculated by the Student's $t$ test. Note that each gene showed a prominent increase in the mRNA expression in response to the hyperosmolar stimulation.

Both genes are osmotically regulated in the SON, and FLJ20037 (Lagali et al., 2002) is expressed preferentially in VP-MCNs, whereas the Riken cDNA is expressed equivalently in OT- and VP-MCNs (Table 3). These two ESTs as well as two other EST clones, BE984462 and AW04654, shown in supplemental Table 1S (available at www.jneurosci.org/cgi/content/full/24/32/7174/ DC1) with expression ratios $>10$ (but with no annotation), represent important sequences to archive, because as for C1q, valuable information about their identity and function may surface with time. Full-length clones from SON RNA must be obtained for all of these genes.

Other genes listed in Table 3 with expression ratios $\geq 3.4$ were studied with regard to their osmotic regulation and cell specificity of expression. These include encephalopsin (ratio, 6.2) (Blackshaw and Snyder, 1999); guanine nucleotide binding protein, $\alpha$ stimulating (ratio, 5.4), reported previously in the SON (Young et al., 1987); calreticulin (ratio, 3.8) (Burns et al., 1994; Dedhar et al., 1994; Platet et al., 2000), glutathione peroxidase 3 (ratio, 10) (Mirault et al., 1994; Chen and Berry, 2003), and Rho GDP dissociation inhibitor $\beta$ (ratio, 3.4) (Bito, 2003). All of these genes increased in expression more than twofold in the SON during hyperosmolar conditions (Table 3 ). Encephalopsin is a mouse
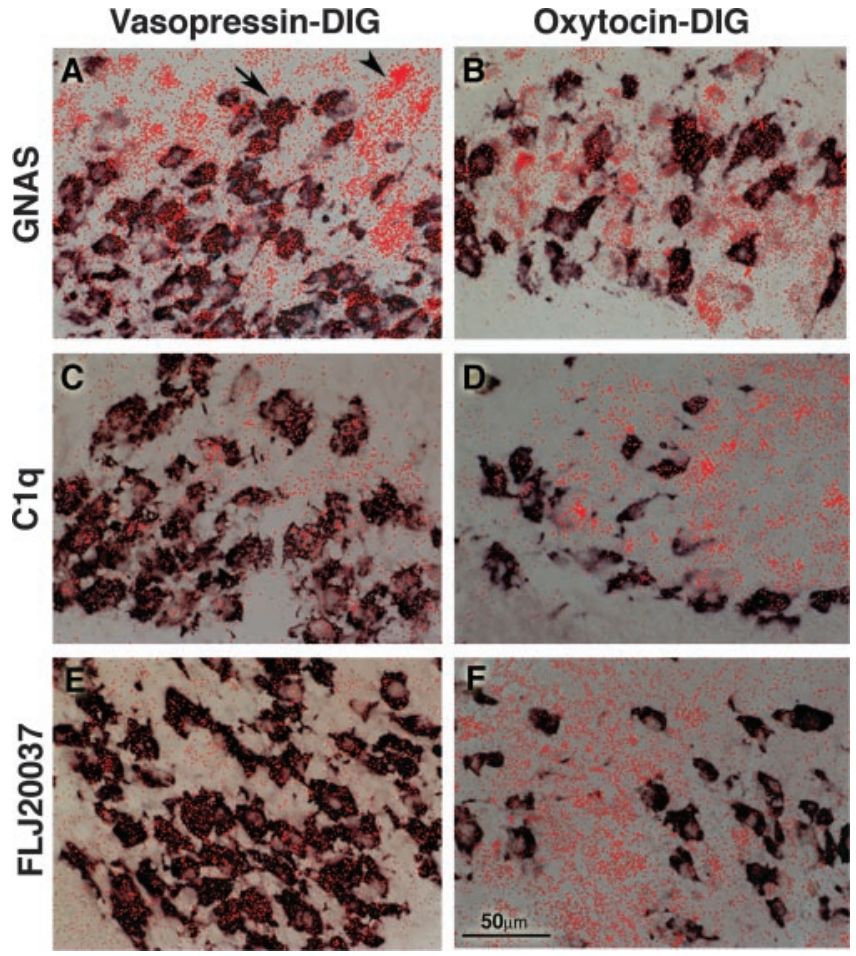

Figure 7. Illustrations of cell-specific gene expression in MCNs in the SON. Frozen sections were made from the SON of male rats and used in double-label ISHH experiments. The doublelabel ISHH was performed using ${ }^{35}$ S-UTP-labeled antisense riboprobes, as was done in the single ISHH experiments (see Figs. 4-6 and Table 1 for probe designs), and a DIG-labeled antisense riboprobe, generated from either an OT or a VP CDNA clone (see Table 1) to identify the phenotype of the MCN. Hybridization of DIG-labeled VP or OT riboprobes stains the cells brownish-purple, and radioactive grains, detected by polarized epifluorescence, were changed to pseudo-red in the figure to improve their visualization. $A, C, E$, Hybridization with DIG-labeled VP probe. $B, D, F$, Hybridization with DIG-labeled OT probe. $A, B$, Cohybridized with GNAS. C, D, Cohybridized with C1q domain containing 1 (C1q) gene. E, F, Cohybridized with FL20037 (EST similar to FL20037) radioactive probes. In A, the arrow shows an example of the mRNA coexpression in VP-DIG (positive) cells, and the arrowhead shows an example of the mRNA expression in a non-VP-expressing (i.e., DIG-negative) cell.

G-protein-coupled receptor gene that was cloned as the first putative extraocular opsin in mammals specifically expressed in the brain (Blackshaw and Snyder, 1999). However, the expression pattern we observed in our ISHH analysis differed from the pre-

Table 3. Changes in mRNA levels of genes expressed in the SON, as a result of hyperosmolar stimulation, and determined by quantitative ISSH

\begin{tabular}{|c|c|c|c|c|}
\hline Clone identification & Gene name & $\begin{array}{l}\text { Expression ratio } \\
\text { (SON/hypothalamus) }\end{array}$ & $\begin{array}{l}\text { Hyperosmolar mRNA level } \\
\text { (percentage of control) }\end{array}$ & $\begin{array}{l}\text { Cell specificity determined } \\
\text { by double-label ISHH }\end{array}$ \\
\hline a & Vasopressin & 44.0 & 238 & ND \\
\hline BE946020 & C1q domain containing 1 & 24.6 & 926 & $\mathrm{VP}>0 \mathrm{~T}$ \\
\hline AW122588 & EST similar to FLJ20037 & 10.7 & 420 & $\mathrm{VP}>0 \mathrm{~T}$ \\
\hline AW550656 & Glutathione peroxidase 3 & 10.0 & 233 & $\mathrm{VP}=0 \mathrm{~T}$ \\
\hline BE992185 & Riken CDNA 2210012L08 & 10.0 & 227 & $\mathrm{VP}>0 \mathrm{~T}$ \\
\hline Al852056 & Zinc finger protein 312 & 9.7 & 217 & $\mathrm{VP}=0 \mathrm{~T}$ \\
\hline AW492784 & Opsin (encephalopsin) & 6.2 & 403 & $\mathrm{VP}=0 \mathrm{~T}$ \\
\hline Al842162 & Guanine nucleotide binding protein, $\alpha$ stimulating & 5.4 & 212 & $\mathrm{VP}=0 \mathrm{~T}$ \\
\hline AW545345 & Calreticulin & 3.8 & 274 & $\mathrm{VP}=0 \mathrm{~T}$ \\
\hline Al842572 & Rho GDP dissociation inhibitor (GDI) $\beta$ & 3.4 & 628 & ND \\
\hline Al836586 & Eukaryotic translation elongation factor $1 \alpha 2$ & 1.6 & 223 & ND \\
\hline AU020383 & PIPPIN (cold shock protein) & 0.9 & 198 & ND \\
\hline Al844075 & LIM only 4 & 0.6 & 208 & ND \\
\hline AU014827 & Putative homeodomain transcription factor & 0.6 & 175 & ND \\
\hline
\end{tabular}

Statistical significance of differences between hyperosmolar and control expression levels were calculated by Student's $t$ test. All the expression changes resulting from hyperosmolar stimulation were found statistically different $(p<0.05)$ among the conditions. ND, Not done.

${ }^{a}$ The VP DNA on the array was PCR amplified from a plasmid containing the rat VP gene (see Materials and Methods). 
vious report in that we found a strong and specific expression in the $\mathrm{SON}$ and in the subfornical region (Figs. $4 E, 5 D$ ). It is possible that the difference in ISHH data could be attributable to use of alternative splice variants of the encephalopsin gene. Additional sequencing and cloning will be necessary to definitively identify this gene in the SON. Calr is a multifunctional protein that acts as a major Ca-binding protein in the lumen of the endoplasmic reticulum. Calreticulin is also located in the nucleus and interacts with DNA-binding domains of nuclear receptors (Burns et al., 1994; Dedhar et al., 1994; Platet et al., 2000). Hence, calreticulin may be involved in the function of estrogen receptor $\beta$ in the MCNs (Somponpun and Sladek, 2003). The Rho GTP dissociation inhibitor $\beta$ (Rho GDI) regulates the GTP-bound and GDPbound state cycle of Rho GTP-binding protein by decreasing the rate of dissociation from ras-like GTPases. Rho GTPases have an important role in neuronal morphogenesis (Bito, 2003), in large part by interacting with the intracellular actin fiber network. What its specific role is in MCNs remains to be determined.

A recent microarray study of the SON (Ghorbel et al., 2003) used a functional criterion (i.e., changes in gene expression with chronic dehydration) to identify potentially interesting genes expressed in the SON. Using a hand-dissection of the SON and an array assay of 1152 gene sequences, they identified 9 genes that were regulated by dehydration. Sequences for four of these genes were also present on our DNA array, and their expression ratios ranged from 0.71 to 1.48 (e.g., the IL- 6 gene ratio was $1.48 \pm$ $0.05)$. Interestingly, however, none of these genes met our expression ratio criterion of $>2$, let alone $\geq 3.4$, and therefore were not SON specific and would have not been pursued using our identification strategy. This point emphasizes that tissue- and cellspecific expression, as reflected by the expression ratio, and functional regulations are independent parameters. We also demonstrate this point by the study of several genes that similarly did not reach an expression ratio of $>2$, but the expression of which was markedly increased by hyperosmolality (Table 3 ). These include the transcription-related genes PIPPin (Castiglia et al., 1996; Raimondi et al., 2003), and LIM only 4 (Kenny et al., 1998; Sugihara et al., 1998). Future experiments will focus on genes exhibiting exceptionally large (in comparison with VP) increases in expression in response to hyperosmolar conditions, such as zinc finger protein 312 (Fez), C1q domain containing 1, EST similar to FLJ20037, opsin, and Rho GD1, because of their potential important roles in regulating OT and VP gene expression in the SON.

\section{References}

Aerbajinai W, Lee YT, Wojda U, Barr VA, Miller JL (2004) Cloning and characterization of a gene expressed during terminal differentiation that encodes a novel inhibitor of growth. J Biol Chem 279:1916-1921.

Antunes-Rodrigues J, de Castro M, Elias LL, Valenca MM, McCann SM (2004) Neuroendocrine control of body fluid metabolism. Physiol Rev 84:169-208.

Bito H (2003) Dynamic control of neuronal morphogenesis by rho signaling. J Biochem (Tokyo) 134:315-319.

Blackshaw S, Snyder SH (1999) Encephalopsin: a novel mammalian extraretinal opsin discretely localized in the brain. J Neurosci 19:3681-3690.

Brownstein MJ, Russell JT, Gainer H (1980) Synthesis, transport, and release of posterior pituitary hormones. Science 207:373-378.

Burbach JP, van Schaick HS, de Bree FM, Lopes da Silva S, Adan RA (1995) Functional domains in the oxytocin gene for regulation of expression and biosynthesis of gene products. Adv Exp Med Biol 395:9-21.

Burbach JP, Luckman SM, Murphy D, Gainer H (2001) Gene regulation in the magnocellular hypothalamo-neurohypophysial system. Physiol Rev 81:1197-1267.

Burns K, Duggan B, Atkinson EA, Famulski KS, Nemer M, Bleackley RC,
Michalak M (1994) Modulation of gene expression by calreticulin binding to the glucocorticoid receptor. Nature 367:476-480.

Castiglia D, Scaturro M, Nastasi T, Cestelli A, Di Liegro I (1996) PIPPin, a putative RNA-binding protein specifically expressed in the rat brain. Biochem Biophys Res Commun 218:390-394.

Chen J, Berry MJ (2003) Selenium and selenoproteins in the brain and brain diseases. J Neurochem 86:1-12.

Chen Y, Dougherty ER, Bittner ML (1997) Ratio-based decisions and the quantitative analysis of cDNA microarray images. J Biomed Opt 2:364-374.

Chen Y, Kamat V, Dougherty ER, Bittner ML, Meltzer PS, Trent JM (2002) Ratio statistics of gene expression levels and applications to microarray data analysis. Bioinformatics 18:1207-1215.

Chomczynski P, Sacchi N (1987) Single-step method of RNA isolation by acid guanidinium thiocyanate-phenol-chloroform extraction. Anal Biochem 162:156-159.

Cortes P, Flores O, Reinberg D (1992) Factors involved in specific transcription by mammalian RNA polymerase II: purification and analysis of transcription factor IIA and identification of transcription factor IIJ. Mol Cell Biol 12:413-421.

Dedhar S, Rennie PS, Shago M, Hagesteijn CY, Yang H, Filmus J, Hawley RG, Bruchovsky N, Cheng H, Matusik RJ, Gigueré V (1994) Inhibition of nuclear hormone receptor activity by calreticulin. Nature 367:480-483.

Dolter KE, Braman JC (2001) Small-sample total RNA purification: laser capture microdissection and cultured cell applications. Biotechniques 30:1358-1361.

Gainer H, Wray S (1994) Cellular and molecular biology of oxytocin and vasopressin. In: The physiology of reproduction (Neil JD, ed), pp 10991129. New York: Raven.

Garber ME, Troyanskaya OG, Schluens K, Petersen S, Thaesler Z, PacynaGengelbach M, van de Rijn M, Rosen GD, Perou CM, Whyte RI, Altman RB, Brown PO, Botstein D, Petersen I (2001) Diversity of gene expression in adenocarcinoma of the lung. Proc Natl Acad Sci USA 98:13784-13789.

Ghorbel MT, Sharman G, Leroux M, Barrett T, Donovan DM, Becker KG, Murphy D (2003) Microarray analysis reveals interleukin-6 as a novel secretory product of the hypothalamo-neurohypophyseal system. J Biol Chem 278:19280-19285.

Glasgow E, Kusano K, Chin H, Mezey E, Young III WS, Gainer H (1999) Single cell reverse transcription-polymerase chain reaction analysis of rat supraoptic magnocellular neurons: neuropeptide phenotypes and high voltage-gated calcium channel subtypes. Endocrinology 140:5391-5401.

Glasgow E, Murase T, Zhang B, Verbalis JG, Gainer H (2000) Gene expression in the rat supraoptic nucleus induced by chronic hyperosmolality versus hyposmolality. Am J Physiol Regul Integr Comp Physiol 279:R1239-R1250.

Hashimoto H, Yabe T, Hirata T, Shimizu T, Bae Y, Yamanaka Y, Hirano T, Hibi M (2000) Expression of the zinc finger gene fez-like in zebrafish forebrain. Mech Dev 97:191-195.

Hollmann M, Hartley M, Heinemann S (1991) Ca2+ permeability of KAAMPA-gated glutamate receptor channels depends on subunit composition. Science 252:851-853.

Kanai Y, Kanai-Azuma M, Noce T, Saido TC, Shiroishi T, Hayashi Y, Yazaki K (1996) Identification of two Sox17 messenger RNA isoforms, with and without the high mobility group box region, and their differential expression in mouse spermatogenesis. J Cell Biol 133:667-681.

Kanai-Azuma M, Kanai Y, Gad JM, Tajima Y, Taya C, Kurohmaru M, Sanai Y, Yonekawa H, Yazaki K, Tam PP, Hayashi Y (2002) Depletion of definitive gut endoderm in Sox17-null mutant mice. Development 129:2367-2379.

Keene JD (2001) Ribonucleoprotein infrastructure regulating the flow of genetic information between the genome and the proteome. Proc Natl Acad Sci USA 98:7018-7024.

Kenny DA, Jurata LW, Saga Y, Gill GN (1998) Identification and characterization of LMO4, an LMO gene with a novel pattern of expression during embryogenesis. Proc Natl Acad Sci USA 95:11257-11262.

Kolble K (2000) The LEICA microdissection system: design and applications. J Mol Med 78:B24-B25.

Lagali PS, Kakuk LE, Griesinger IB, Wong PW, Ayyagari R (2002) Identification and characterization of C6orf37, a novel candidate human retinal disease gene on chromosome 6q14. Biochem Biophys Res Commun 293:356-365. 
Levkowitz G, Zeller J, Sirotkin HI, French D, Schilbach S, Hashimoto H, Hibi M, Talbot WS, Rosenthal A (2003) Zinc finger protein too few controls the development of monoaminergic neurons. Nat Neurosci 6:28-33.

Luo L, Salunga RC, Guo H, Bittner A, Joy KC, Galindo JE, Xiao H, Rogers KE, Wan JS, Jackson MR, Erlander MG (1999) Gene expression profiles of laser-captured adjacent neuronal subtypes. Nat Med 5:117-122.

Ma D, Olave I, Merino A, Reinberg D (1996) Separation of the transcriptional coactivator and antirepression functions of transcription factor IIA. Proc Natl Acad Sci USA 93:6583-6588.

Matsuo-Takasaki M, Lim JH, Beanan MJ, Sato SM, Sargent TD (2000) Cloning and expression of a novel zinc finger gene, Fez, transcribed in the forebrain of Xenopus and mouse embryos. Mech Dev 93:201-204.

Melloul D, Marshak S, Cerasi E (2002) Regulation of insulin gene transcription. Diabetologia 45:309-326.

Mirault ME, Tremblay A, Furling D, Trepanier G, Dugre F, Puymirat J, Pothier F (1994) Transgenic glutathione peroxidase mouse models for neuroprotection studies. Ann NY Acad Sci 738:104-115.

Murre C, McCaw PS, Baltimore D (1989) A new DNA binding and dimerization motif in immunoglobulin enhancer binding, daughterless, MyoD, and myc proteins. Cell 56:777-783.

Park-Lee S, Kim S, Laird-Offringa IA (2003) Characterization of the interaction between neuronal RNA-binding protein $\mathrm{HuD}$ and AU-rich RNA. J Biol Chem 278:39801-39808.

Perou CM, Sorlie T, Eisen MB, van de Rijn M, Jeffrey SS, Rees CA, Pollack JR, Ross DT, Johnsen H, Akslen LA, Fluge O, Pergamenschikov A, Williams C, Zhu SX, Lonning PE, Borresen-Dale AL, Brown PO, Botstein D (2000) Molecular portraits of human breast tumours. Nature 406:747-752.

Perrone-Bizzozero N, Bolognani F (2002) Role of HuD and other RNAbinding proteins in neural development and plasticity. J Neurosci Res 68:121-126.

Phillips J, Eberwine JH (1996) Antisense RNA amplification: a linear amplification method for analyzing the mRNA population from single living cells. Methods 10:283-288.

Platet N, Cunat S, Chalbos D, Rochefort H, Garcia M (2000) Unliganded and liganded estrogen receptors protect against cancer invasion via different mechanisms. Mol Endocrinol 14:999-1009.

Quackenbush J (2002) Microarray data normalization and transformation. Nat Genet [Suppl] 32:496-501.

Raimondi L, D’Asaro M, Proia P, Nastasi T, Di Liegro I (2003) RNAbinding ability of PIPPin requires the entire protein. J Cell Mol Med $7: 35-42$.

Robertson GL (1995) Posterior pituitary. In: Endocrinology and metabo- lism (Felig P, Baxter JD, Frohman LA, eds), pp 385-432. New York: McGraw-Hill.

Roeder RG (1991) The complexities of eukaryotic transcription initiation regulation of preinitiation complex assembly. Trends Biochem Sci 16:402-408.

Sladek CD (1999) Hormonal regulation of water and electrolyte balance. Antidiuretic hormone: synthesis and release. In: Handbook of physiology, Sec 7, The endocrine system, Vol 3, Endocrine regulation of water and electrolyte balance (Fray JCS, ed), pp 436-495. Oxford: Oxford UP.

Somponpun SJ, Sladek CD (2003) Osmotic regulation of estrogen receptor- $\beta$ in rat vasopressin and oxytocin neurons. J Neurosci 23:4261-4269.

Sugihara TM, Bach I, Kioussi C, Rosenfeld MG, Andersen B (1998) Mouse deformed epidermal autoregulatory factor 1 recruits a LIM domain factor, LMO-4, and CLIM coregulators. Proc Natl Acad Sci USA 95:15418-15423.

Waller SJ, Ratty A, Burbach JP, Murphy D (1998) Transgenic and transcriptional studies on neurosecretory cell gene expression. Cell Mol Neurobiol 18:149-171.

Xiang CC, Kozhich OA, Chen M, Inman JM, Phan QN, Chen Y, Brownstein MJ (2002) Amine-modified random primers to label probes for DNA microarrays. Nat Biotechnol 20:738-742.

Xiang CC, Chen M, Ma L, Phan QN, Inman JM, Kozhich OA, Brownstein MJ (2003) A new strategy to amplify degraded RNA from small tissue samples for microarray studies. Nucleic Acids Res 31:e53.1-5.

Yamashita M, Glasgow E, Zhang BJ, Kusano K, Gainer H (2002) Identification of cell-specific messenger ribonucleic acids in oxytocinergic and vasopressinergic magnocellular neurons in rat supraoptic nucleus by singlecell differential hybridization. Endocrinology 143:4464-4476.

Yang IV, Chen E, Hasseman JP, Liang W, Frank BC, Wang S, Sharov V, Saeed AI, White J, Li J, Lee NH, Yeatman TJ, Quackenbush J (2002) Within the fold: assessing differential expression measures and reproducibility in microarray assays. Genome Biol 3:research0062.1-0062.12.

Yang Z, Liu N, Lin S (2001) A zebrafish forebrain-specific zinc finger gene can induce ectopic dlx2 and dlx6 expression. Dev Biol 231:138-148.

Young III WS, Mezey E, Siegel RE (1986) Vasopressin and oxytocin mRNAs in adrenalectomized and Brattleboro rats: analysis by quantitative in situ hybridization histochemistry. Brain Res 387:231-241.

Young III WS, Shepard EA, Burch RM (1987) Plasma hyperosmolality increases $G$ protein and $3^{\prime}, 5^{\prime}$-cyclic adenosine monophosphate synthesis in the paraventricular and supraoptic nuclei. Mol Endocrinol 1:884-888.

Young WSI (1992) Expression of the oxytocin and vasopressin genes. J Neuroendocrinol 4:527-540. 